\title{
ARTICLES
}

Submitted 02.26.2018. Approved 10.18.2018

Evaluated through a double-blind review process. Scientific Editor: Eliane Brito

Original version

DOI: http://dx.doi.org/10.1590/So034-759020190302

\section{INTERTEXTUAL VIRALITY AND VERNACULAR REPERTOIRES: INTERNET MEMES AS OBJECTS CONNECTING DIFFERENT ONLINE WORLDS}

\author{
Viralidade intertextual e repertórios vernaculares: Memes da Internet como \\ objetos conectando diferentes mundos on-line \\ Viralidad intertextual y repertorios vernaculares: Memes de Internet como \\ objetos que conectan diferentes mundos on-line
}

\begin{abstract}
This work describes the trajectory of Internet memes, their main characteristics, and their relationship with the fields of virality literature and cultural production research. We explore the historical trajectory of internet memes and identify their constitutional features (vernacularism, virality, and intertextuality). We also propose that memes are objects that act as provocateurs; this is because they are carriers of meaning that reflect the repertoires of closed communities. However, they acquire new reflected repertoires in the process of being transmitted intertextually among consumers. As such, this work both clarifies the intertemporal and logical interdependencies between online cultural production and virality, as well as unveil the linking power of vernacular backgrounds and shared expressive practices (in our context, elaboration of common memes) for online consumer collectivities.
\end{abstract}

KEYWORDS | Internet memes, consumer collectivities, virality, intertextuality, repertoires.

MARIA CAROLINA

ORCID: 0000-0001-9245-8710

IZIDORO BLIKSTEIN ${ }^{2}$

izidoro@blikstein.com

ORCID: 0000-0003-2958-4524

LUCA M. VISCONTI 34

luca.visconti@usi.ch

ORCID: 0000-0001-6036-7099

${ }^{1}$ Ecole Superieure Libre des Sciences Commerciales Appliquees, Paris, France

${ }^{2}$ Fundação Getulio Vargas, Escola de Administração de Empresas de São Paulo, São Paulo, SP, Brazil

3Universita della Svizzera Italiana, Lugano, Switzerland

${ }^{4}$ ESCP Europe Business School, Paris, France

\section{RESUMO}

Este trabalho descreve a trajetória dos memes da Internet, suas principais características e suas conexões com os conceitos de viralidade e pesquisa em produção cultural. Nós exploramos a trajetória histórica dos memes e identificamos seus elementos principais (vernacularismo, viralidade e intertextualidade). Também propomos que os memes representam objetos que atuam como provocadores, pois são portadores de significado que refletem repertórios de comunidades fechadas, mas que adquirem novos repertórios refletidos à medida que são transmitidos entre consumidores de modo intertextual. Assim, este trabalho tanto esclarece as interdependências intertemporaius e logicas entre produção cultural e viralidade, bem como revela o poder conector de cenários vernaculares e práticas expressivas compartilhadas para coletividades de consumidores online.

PALAVRAS-CHAVE I Memes da Internet, coletividades de consumidores, viralidade, intertextualidade repertórios.

\section{RESUMEN}

Este trabajo describe la trayectoria de los memes de Internet, sus principales características y sus conexiones con los conceptos de viralidad y colectividades de consumidores, bien establecidos en marketing e investigación del consumidor. Nosotros proponemos que los memes representan objetos que actúan como provocadores, pues son portadores de significado que reflejan repertorios de comunidades cerradas, pero que adquieren nuevos repertorios reflejados a medida que se transmiten entre consumidores de forma intertextual. Finalmente, discutimos las implicaciones de las características de este fenómeno.

PALABRAS CLAVE I Memes de internet, colectividades de consumidores, viralidad, intertextualidad, repertorios. 


\section{INTRODUCTION}

Internet memes are a recent consumer-created phenomenon that has penetrated the "real" world in the past few years. Traditional media and social media debates, in general, emphasized the role of memes in the North American elections (Beran, 2017) as one of the communicative forces responsible for Donald Trump's victory. The debate about Internet memes as tools of advocacy and provocateur objects (Mina, 2017) has led to greater attention being paid to the usage of these digital artefacts, as well as their creation and spread by consumers.

A meme is a concept propounded by Richard Dawkins and later addressed by Susan Blackmore's book The Meme Machine (Blackmore, 2000). According to these authors, memes are the cultural parallel of biological genes because they are transferred from person to person; however, they may be modified in this transmission process. In an online context, the term "meme" first appeared when Wired magazine's journalist, Mark Godwin (Godwin, 1994), conducted an "online experiment" focusing on discussion fora to characterize the proliferation of "Hitler-like" arguments.

From a spreadable idea, memes evolved to become complex artefacts that are rich in cultural meanings and popular references. Consumers started illustrating these spreadable ideas with images or videos. Furthermore, specific Internet communities became meme-generators through co-creative consumer environments (Kozinets, Hemetsberger, \& Schau, 2008). Internet memes have evolved in parallel with the web itself (Börzsei, 2013).

Given the importance of this phenomenon, it is surprising to note that this theme, has only been scarcely addressed in the consumer and marketing research (Rosenthal, 2014; Wu \& Ardley, 2007). This lack of work is surprising when one considers that memes are present in the literatures of two of the most explored theoretical areas in consumer research: (1) consumer collectivities, a term that we here use to address a variety of online social groups usually sharing cultural repertoires that span from fora to communities, and from brand publics to interest groups (Arvidsson \& Caliandro, 2015; Muñiz \& Schau, 2011; Schau, Muñiz, \& Arnould, 2009; Schouten \& Mcalexander, 1995; Thomas, Price, \& Schau, 2012), and (2) the phenomenon of viral marketing and word-of-mouth promotion (Brown, Broderick, \& Lee, 2007; Dellarocas, 2006; Godes \& Mayzlin, 2004; Groeger \& Buttle, 2014; Kozinets, Valck, Wojnicki, \& Wilner, 2010; Miles, 2014; Phelps, Lewis, Mobilio, Perry, \& Raman, 2004).

One possible reason why the phenomenon has been overlooked could be that it is only recently that consumer and marketing research have shown interest in phenomena related to language and its complexities, or the linguistic turn in general (Thompson, Arnould, \& Giesler, 2013). This article is located at the intersection of the Internet memes literature, which is strongly indebted to media and visual culture studies, and of consumer and marketing research. Thus, its broader aim is to advance consumer and marketing literature on Internet memes, which to date is not only scant but also relatively scattered. We identify two main streams of studies using Internet memes to illuminate relevant and distinct marketing topics. First, researchers interested in Internet memes to sharpen understanding about the underlying mechanisms of online virality, an effect of outmost marketing relevance. These scholars approach memes as a fertile ground to inspect the unfolding of emotional contagion (Guadagno et al., 2013) within online settings, and adapt medical epistemological models to explain consumer behavior (Bauckhage, 2011). Second, consumer and marketing scholars have also dedicated attention to Internet memes since they would help clarify the logics of online cultural production (Knobel \& Lankshear, 2007; Nissenbaum \& Shifman, 2017). An additional, more focused aim of this article is to start inquiring about the links between online consumer collectivities and their shared expressive practices (Internet memes being one of them), thus advancing the abovementioned linguistic turn in consumer and marketing studies (Thompson et al., 2013).

In order to pursue said objectives, we relied upon two sources of information. First, an extensive literature review of the three streams that are relevant for the declared purposes: (1) Internet memes; (2) virality literature; and, (3) cultural production research (e.g. contributions dealing with cultural repertoires and vernacularism). Second, two empirical cases of Internet memes, Inbonha and Chola Mais, both retrieved from the Brazilian context. Relying upon these sources, the article traces Internet memes' historical trajectory and identifies their constitutional features (vernacularism, virality, and intertextuality). Within the conclusion and discussion section, we then extrapolate two main theoretical contributions of the work. A first theoretical contribution is to be found in the article's ability of linking Internet memes research on cultural production and on virality together. Our interpretive model accounts for how cultural production precedes (through vernacularism), and follows (through intertextuality), virality. As such, this work sews extant consumer and marketing contributions inspired by Internet memes, by clarifying the intertemporal and logical interdependencies between online cultural production and virality. A second theoretical contribution derives from the preliminary unveiling of the linking power of vernacular backgrounds and shared expressive practices (in our context, elaboration of common memes) for online consumer collectivities. Article's content organization reflects the reported sequence, thus 
bringing the reader through the three streams of relevant literature, to then introduce the empirical cases and derive contributions and implications for consumer and marketing theory and practice.

\section{INTERNET MEMES: THEIR DEVELOPMENT AND MAIN CHARACTERISTICS}

The first registered Internet meme was the smiling face (Davison, 2012). It was used as a way of solving problems arising from ambiguity in online fora; its visual cue, composed of a colon and a parenthesis, indicated that a particular post was either ironic or funny.

As technology evolved and Internet access spread to ordinary users, other memes started to appear. Two examples from the 1990 s and early 2000 s include Bert is Evil and The Tourist Guy. Bert is Evil refers to the picture of a cartoon character juxtaposed with tragic historical events. It spread online circa 1997 through the creation of websites that replicated the meme (Börzsei, 2013). The Tourist Guy, on the other hand, consists of a montage with a photo of a tourist in front of the World Trade Center, right before the airplane crash in 2001. After the picture went viral, consumers started placing the same man in front of other relevant and tragic political events and sending them through e-mail, in a typical "Internet chain” (Börzsei, 2013).

In the early 2000 s, technology changes increased access to the web. These changes also altered the web's configuration, creating an environment conducive to the emergence of a participatory culture (Jenkins, 2006). Social media emerged as an essential point of convergence for consumers who participated in collectivities that shared the same interests, including brands and consumption communities (Fournier \& Lee, 2009; Stratton \& Northcote, 2014). These online groups becamethe spaces for the creation of common digital artifacts, shared rituals, and everyday practices (Muñiz \& Schau, 2011; Schau et al., 2009). Memes are one type of community-created object that spread to different communities.

Most memes follow a typical pattern of an image juxtaposed with a written caption (both image and text can be modified during transmission), which carries an ironic, politically incorrect, and sometimes grotesque message (Horta, 2015). In that sense, memes are provocateur objects. The elements that compose the object have an impact on the receivers (Benveniste, 1974). This provocative function makes the meme disruptive; it contains an unexpected, subversive element that does not conform to the stereotypes that govern the perception of the community of receivers.
In extreme cases, memes' grounding on provocation and meaning subversion result into trolling practices. Internet Trolling is the act of disrupting online conversations for the sake of doing so (just for the lulz), even if it includes harassing people or perpetuating controversial discourses (Phillips, 2015). According to Phillips' (2015) study of Internet trolls, these individuals organize themselves as groups on different social media sitesfrom obscure discussion fora to Facebook-and plan controversial actions on online communities and in their interactions with other consumers. As such, trolling represents a deviant expression of memes. Further, Phillips states that the trolling culture was fostered in a particular subcultural environment called 4 chan.

4 chan was a forum created by a person named moot when he was still a teen; it was meant to be a space to discuss anime (a category of cartoons or comics usually related to Japanese culture). Not long after its creation, users opened several boards (consumer-owned fora) for discussing different subjects. Of all the boards that composed 4chan, the / b/ board became the most popular. The main subject of discussion on the / b/ board was characterized as "random," that is, consumers could post about any topic.

Several "classic memes," such as the famous series LOLcats and Advise Animals were created between 2003 and 2011 (Börzsei, 2013; Phillips, 2015; Shifman, 2014). These memes reflected the cultural ethos, or repertoire (Blikstein, 2016), of 4 channers because many of them were created or popularized on the /b/board; these consumers created, just for the lulz, disruptive and politically incorrect content that would soon go viral. For Phillips (2015), these memes and online actions that generated trolling consisted of juxtaposing death and destruction with pop cultural iconography.

From 2012 to 2015, the 4 channers subculture was virtually dissolute, as Internet memes became mainstream (most consumers learned to use the object). The occurrence of two events made this possible. First, the platform Know Your Meme was created; this was a community where meme enthusiasts helped institutionalize memes by clarifying the foundational traits of these artifacts and by explaining their meaning and histories. Second, this platform was acquired by "Cheezburger," a commercial website that interfaced online subcultures and companies (Phillips, 2015). Furthermore, the technological skills required to create Internet memes were reduced substantially with the creation of platforms, such as Meme Generator, in 2009; this allowed Internet users without much knowledge of image editing skills to create their memes based on constituted and popular image macros. Figure 1 depicts the Internet memes mentioned so far. 
Figure 1. Examples of Internet memes

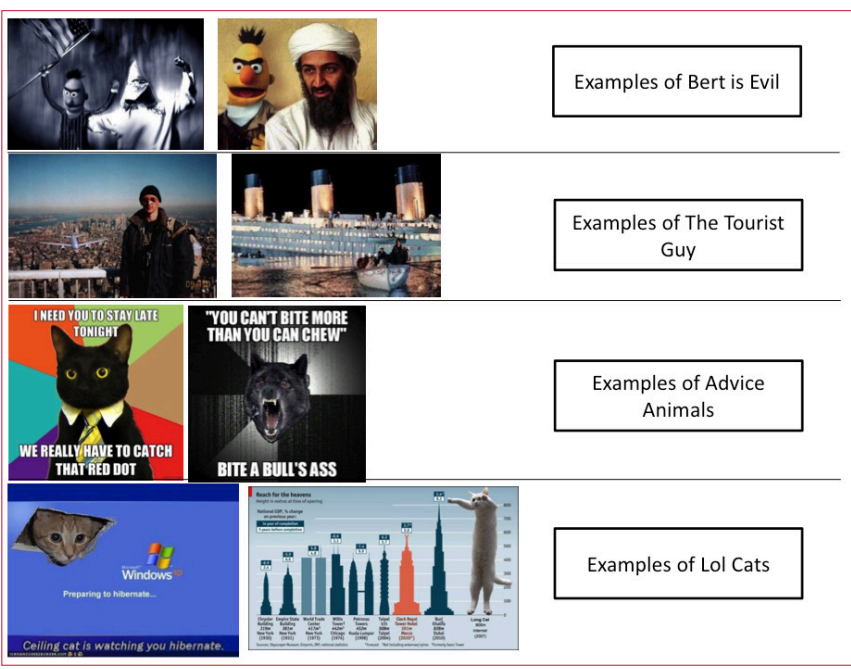

Source: Retrieved from Know Your Meme website: https://knowyourmeme.com/

As previously described, memes were historically created informally and at a specific "location" (closed consumer collectivities); from there, they spread and were modified by consumers. As such, two theoretical elements should be analyzed concerning the nature of Internet memes and their interactions with marketing practice and consumer research: intertextual virality and vernacular repertoires. We will discuss both these concepts in detail in the next sections.

\section{INTERTEXTUAL VIRALITY: REPRODUCTION OF INTERNET MEMES AND THEIR RELATION TO MARKETING AND CONSUMER RESEARCH}

"Viral marketing" has become a particular model in contemporary marketing management. According to Douglas Holt (2004), viral marketing is an attempt to connect brand strategy to what is fashionable (in Internet terms, something that is trending) at a particular moment; for example, it could be something being discussed on social media at a specific time. Virality is a term used by the industry to refer to these pieces of content, such as advertisements or consumer-created content, which are shared through social media by consumers, and go on to become trends or the most discussed topics at a particular moment on platforms, such as Facebook or Twitter.

Given the amount of attention this term has generated in the area of marketing, several studies have been conducted since the 1980 s on consumer behavior and consumer research to understand how the transmission of content occurs. However, even before field of marketing took notice of this phenomenon, other social sciences had examined it. Studies such as the one produced by Katz and Lazarsfeld (1955) in the 1950 s attempted to understand information transmission through the concept of personal influence. The authors developed a theory regarding the two-step flow of communication wherein influent peopleindividuals, with many loose connections, who are central to a network-have a prominent role as gatekeepers of the type of information that will be spread.

Marketing research has mainly sought to understand how this word-of-mouth behavior affects companies. Referrals, the pieces of information that are transmitted among consumers (influential or not), emanate from, and are limited by, the social relations of consumers with one another (Brown \& Reingen, 1987; Reingen, Foster, Brown, \& Seidman, 1984). The information disclosed by consumers (referrals) seems to have more credibility than traditional communication, that is, information that emanates from the company and is sent to the client (Allsop et al., 2007). Moreover, the effect of this information is more enduring that of media content or business information reports (Trusov, Bucklin, \& Pauwels, 2009). The weight consumers give to referrals has led to word-of-mouth being studied in the literature as a driver of buying behavior; it is seen as an element that emerges from the structure of social ties, and is the result of prior consumer behavior (Godes \& Mayzlin, 2004). With the emergence of social media and the remarkable influence it had in facilitating the spread of content, word-of-mouth/word-of-mouse marketing has gained even more attention both in the literature and in practice (Allsop, Bassett, \& Hoskins, 2007; Watts \& Dodds, 2007). To date, research on viral marketing has more focused on the effects of virality (e.g., its impact in terms of engagement, loyalty or sales) than on its determinants. This has resulted into this research field's unpredictability; marketers understand the transmission of information but are unsure about what type of content makes something go viral (Miles, 2014). Contagion in marketing discourses is a consumption-based activity that is characterized by both a challenge and an opportunity for marketers.

These theories of reproduction, contagion, referrals, or word-of-mouth/mouse behavior apply to Internet memes since one of their main characteristics is reproduction. Wiggins and Bowers (2014) state that before an Internet meme starts to be reproduced with modifications (which makes it a meme), it has to become a viral, or, in their terms, an emerging meme. This means that virality is the precondition to reproduction. Through reproduction, the original meme becomes a text of reference to 
be quoted and changed along its circulation, a process known as intertextuality (the implicit quotation of a text in another text, whose meaning becomes richer by referencing to the implicit text).

Intertextuality consists of a linguistic-semiotic process by which the meaning of a text (image, words) is modified, enlarged, or reduced by combining it with other texts (Blikstein, 2016). Thus, in the creation of an Internet meme, the meaning of the original image or text is modified by other texts or images, thereby acquiring new connotations that may be marked by irony, sarcasm, blunt criticism, and so on. As we mentioned earlier, as an object, the meme does not inform; instead, it acts provocatively, subverting an expected response or a predicted text. It is necessary, however, to point out a problem: for the Internet meme to have the impact expected by the consumer who shares or uses it, it must engage in a dialogue with the repertoires of different consumer collectivities.

\section{VERNACULAR REPERTOIRES}

In this section, we make the case that these contents are particularly prominent in Internet memes. Other than virality, the consumer communities that gave rise to the most popular memes in the period had specific repertoires (Blikstein, 2016), which Internet memes carried as they spread online through modified reproductions. According to Blikstein (2016), a repertoire is a crucial piece of the communicative process. Repertoires refer to knowledge and to historical, geographic, affective, professional, artistic, scientific, mystical, and religious, references, among others, that are lived by individuals in the course of their lives. This network of references and knowledge constitutes the cultural baggage of individuals, also referred to as their repertoire. However, this network varies from community to community. It is possible to say that different communities create different repertoires.

As such, any type of communication, whether we consider how the message is sent or how it is decoded, will be influenced by such repertoires. Different repertoires lead to different ways of perceiving the world, people, and events. From these differences in understanding, many noises begin to infiltrate the communication, jamming its mechanism. The same message is then decoded differently by different repertoires-meaning that individuals within communities that have taught them different repertoires will decode a message differently. Decoding, therefore, depends not only on the knowledge of the code but also on the repertoire of the individual who receives the message.

Linguistically, repertoires are manifested in vernacular language. Briefly, vernacularity refers to an informal production (produced by non-institutional sources) of discourse (Howard, 2005, 2009; Milner, 2013); it can be understood even as the oral traditions of particular communities. The way we use the expression here coincides with its use in folklore studies, a traditional field that focuses on vernacular manifestations (Sims \& Stephens, 2011). When viewed through this lens, vernacularity tends to refer to that which is locally produced: local repertoires that manifest in linguistic and discursive tropes or other manifestations that reflect these repertoires. In sum, repertoires reflect cultural characteristics that are manifested and comprehended in a vernacular of these local communities.

However, in the digital world, the importance of geography in defining community boundaries has been replaced by other kinds of "localities." As geographic locations lost significance in the creation of repertoires and consumption gained influence as one of the most important symbolic cornerstones of postmodern life (Stratton \& Northcote, 2014), individuals and consumers began to organize themselves in online consumer collectivities, where, through different practices (Schau et al., 2009), they vernacularly create historical, professional, artistic, scientific, mystical, and even religious repertoires (Muñiz \& Schau, 2005).

Many of the consumer collectivities that have been studied in the previous literature share some characteristics, such as the constitution of a consumer's identity as deviant because cultural practices in the consumer collectivity are subcultural, the worship of specific consumer objects or brands, and the shared ethos and rituals that take place in this (not necessarily physical) locus (Fournier \& Lee, 2009; Stratton \& Northcote, 2014; Thomas et al., 2012). These characteristics are typical of consumer collectivities called subcultures.

Schouten and McAlexander (1995) indicate that subcultures represent a distinct subset of society that self-selects, based on a mutual commitment to a particular class of products, brands, or consumer activities. Kates (2004) indicates that a subculture is a way of life that expresses shared meanings and practices, but which also encompasses changes, challenges, and internal opposition so that the participants define their identities by negotiating them with the subcultural aspects, which are "deviant" when compared with the dominant social discourse (Kozinets, 2001).

As we have mentioned during our brief recount of the history of memes, "the golden age" of Internet memes occurred during the year when 4chan, an online discussion board permeated by the culture of trolling, was most popular (Phillips, 2015). The characteristics of 4 chan, as an online consumer collective, make it a subculture (deviant character, besides shared ethos and rituals). As such, both repertoires and the vernacular connected to them have emerged in this environment. 
Therefore, once we consider the brief history of memes and the theories that help to explain their functioning, it is possible to assert that these vernacular repertoires, created inside closed digital environments, are re-worked and re-used by consumers as memes go viral, along with the modifications that are made to them. The meme carries different repertoires, which are modified by intertextuality, and become provocateur objects when these repertoires are used in various vernacular contexts. Two examples are given in the next section to illustrate our argument.

\section{DESCRIBING INTERNET MEMES AS PROVOCATEUR CARRIERS OF VERNACULAR REPERTOIRES}

\section{Procedure for selecting the memes}

To illustrate our arguments regarding Internet memes, we will describe two prominent examples of Internet memes that have emerged recently in Brazilian social media among consumer collectivities with different repertoires. We follow similar studies, such as those of Schroeder and Zwick (2004) and Scott and Vargas (2007), who use representative figures, which are analyzed textually (Scott, 1994, 2009), to derive meanings that are representative of theory.

To select the memes that would be analyzed as useful and compelling representations that illustrate our argument, we have used two primary sources. Two of the authors of this paper have been immersed in a long-term project regarding Internet memes and acknowledge the main popular consumer collectivities in which the most popular Internet memes emerge. In the Brazilian context, a Facebook group called LDRV (this is an abbreviation of Lana del Ray Vevo; the group was initially created as a space to celebrate the singer Lana del Rey) is regarded as the "Brazilian factory machine" (Declercq, 2017). LDRV is a closed Facebook group with more than 200,000 members in which consumers post daily doubts, situations, and happenings. As a story from Vice magazine reports, the first Internet meme analyzed here emerged in that particular group. This meme uses images of the popular characters in Brazilian comics, called Turma de Monica (Monica's Gang). Considering the popularity of this first Internet meme using Turma da Monica's characters, a search on the Know Your Meme platform was performed, looking for emerging memes based on the same popular characters, resulting in the choice of the second Internet meme analyzed. To choose the particular images to be analyzed, a search of Twitter pictures was conducted using the names of the emerging memes (Inbonha and Chola Mais).

\section{Intertextual repertoires in Inbonha and Chola Mais}

The first meme chosen was "Inbonha." According to Declercq (2017), the "Inbonha" meme emerged in LDRV when a member of the group posted the picture shown in Figure 2. The picture represents a child's attempt to write the names of the main characters of Turma da Monica. However, all of them are incorrectly named. Monica, the most iconic character, for example, is named "Inbonha" in the figure 2.

Figure 2. The "Inbonha” meme



Source: Evangelista (2016b)

\section{Graph 1. Search trends for the term "Inbonha"}

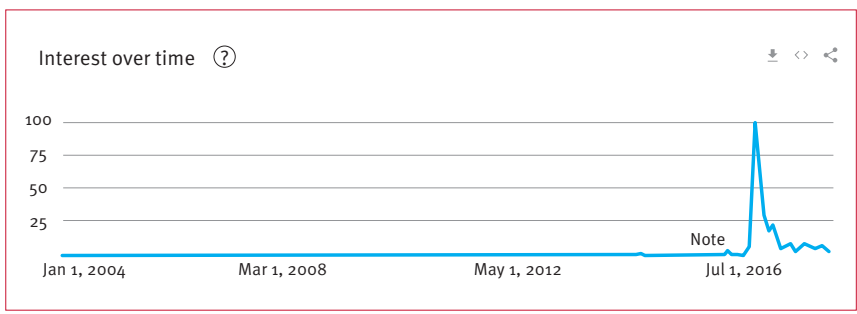

Note: The graph indicates the peak in popularity (100) and proportion of searches. Source: Retrieved from Google Trends: https://trends.google.com/trends/?geo=US 
The spread of the meme in social media in general (meaning outside of the particular Facebook group) - that is, its viralizationoccurred mainly when two stories on the subject were published on the website Buzzfeed. The first was about the girl who misspelled the names of the characters (Evangelista, 2016b), and the other was about the repercussions of the meme in other online communities (Evangelista, 2016a). Graph 1 illustrates that the search for the term "Inbonha" on Google peaked in September 2016, the month when the stories were published. As such, the Inbonha picture went viral; it became very well-known not only in the community where it first emerged, but also on the Internet in general, thereby constituting an emerging meme. This emerging meme (Wiggins \& Bowers, 2014) carried a repertoire (Blikstein, 2016) that reflected the subculture of the LDRV group: ironic, playful, and centered on current pop-culture issues and queer subcultural practices (Declercq, 2017). However, after the Inbonha picture went viral, different manifestations of this meme started to appear.

\section{Figure 3. Example of intertextuality}

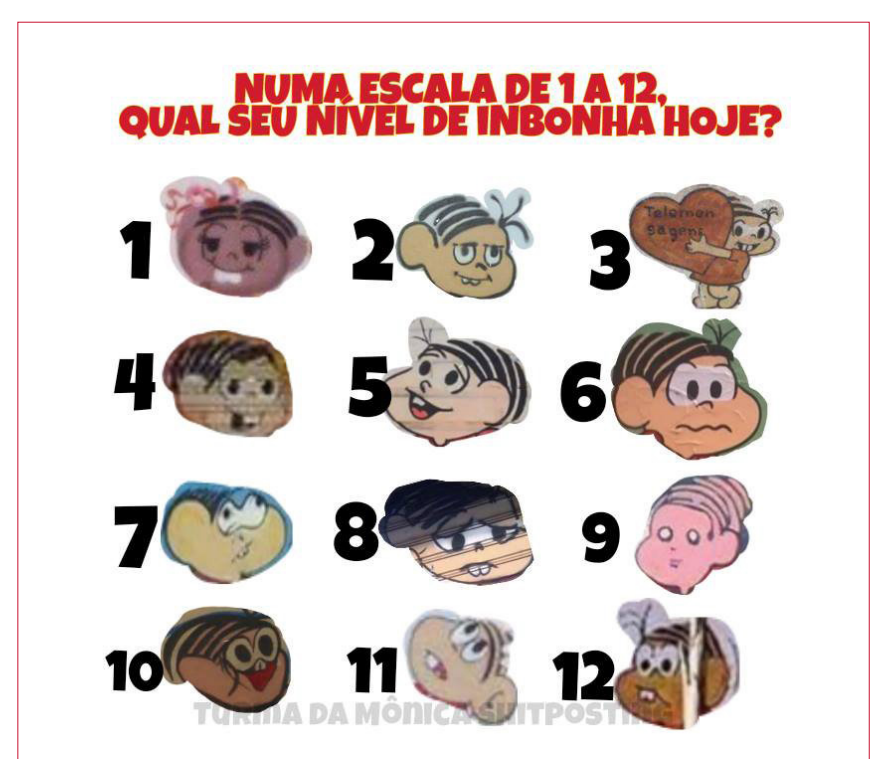

Note: The caption reads, "on a scale of 1 to 12 , what is your Inbonha level today?" Source: Retrieved from Twitter's search engine based on a keyword search for "Inbonha."

Figure 3 provides an example of the intertextual modifications of the meme, where the image can be understood only if the audience has knowledge of three different emerging memes, or viral messages, that were combined to form this image. The first one is Inbonha, as the title of the meme (the written part) suggests by saying "On a scale of 1 to 12 , what is your level of Inbonha today?" The second is "On a Scale of 1 to X." This meme refers to the viral practice of juxtaposing pictures of celebrities or other well-known figures depicting different emotions or feelings and attributing numbers to each picture to elicit a response in the picture's receivers ("On a Scale of 1 to X," 2012). The third emerging meme that is referred to in the picture is "Deformed Monicas in School Walls" (Metropoles, 2016), which refers to a Facebook page ("Mônicas Deformadas em Muros de Escolinhas," 2018) that are devoted only to pictures of Monica that do not accurately depict her (painted mainly on school walls). By merging these three emerging memes altogether, the newly created meme joined different repertoires. The audience understands that this highly intertextual meme requires the knowledge that the emerging Inbonha meme will necessarily lead to a mischaracterization of Monica. Second, the scale eliciting reactions presupposes different versions of the Monica character. Finally, by using the poorly drawn Monicas, the meme creates congruence with the cultural repertoire coming from the idea of Inbonha (childish, poorly made, and wrong).

Thus, to understand this last meme, the reader must have previous knowledge of emerging and other memes. Thus, there are two critical points to be addressed. First, the emerging meme carries a repertoire that derives from the vernacular environment in which it was created. Second, the modifications that happen intertextually as the meme spreads add different repertoires to the message. They turn the object into a complex network of meanings, which, to be understood, require different types of knowledge on the part to the receivers.

\section{Figure 4. The Chola Mais meme}

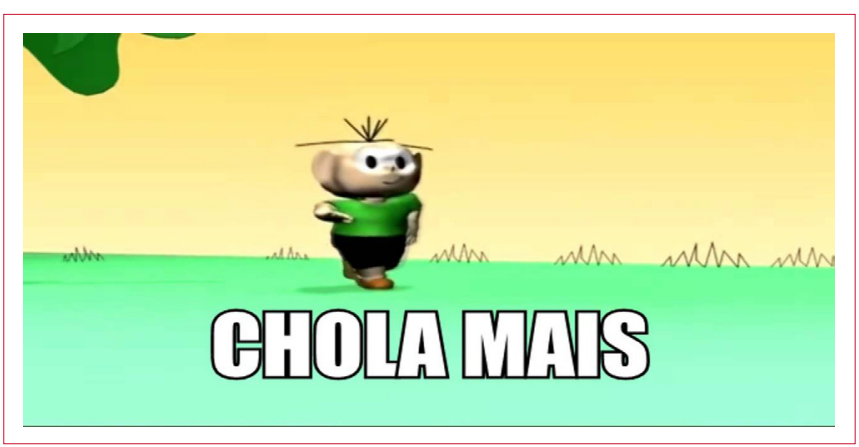

Source: Retrieved from Know Your Meme website: https://knowyourmeme.com/

\section{Graph 2. Trends for the search of the term "Chola Mais"}

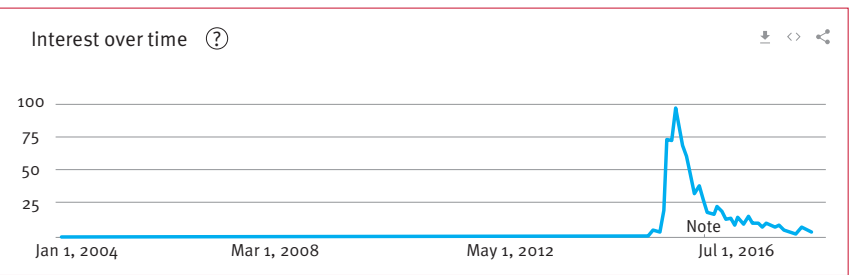

Note: The graph indicates the peak in popularity (100) and proportion of searches. Source: Retrieved from Google Trends: https://trends.google.com/trends/?geo=US 
The second meme in this paper is "Chola Mais," which depicts the a poorly designed $3 \mathrm{D}$ animation of a character called Cebolinha celebrating a video against Monica with a Japanese anime song remix ("Chola Mais/Cwy Mowe," 2016), depicted in Figure 4. Graph 2 shows the search trends for the term "Chola Mais." As the graph indicates, the peak was in the middle of the year 2015, when protests against former Brazilian president Dilma Roussef, which followed a wave of street demonstrations in Brazil (Castells, 2012; Rosenthal, 2014), were happening around the country and protesters were asking for her impeachment.

\section{Figure 5. The Chola Mais meme in a soccer context}

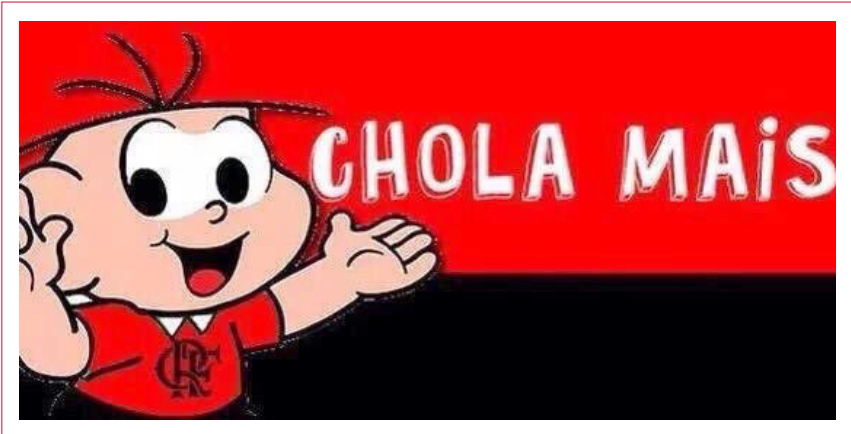

Source: Retrieved from Know Your Meme website: https://knowyourmeme.com/

A second search on Twitter shows that the meme is modified with regard to the repertoire it reflects by following two subjects: soccer and politics. Regarding soccer, modifications on the meme occur when a soccer team achieves a critical victory. As Figure 5 illustrates, the meme indicates that the team's victory should make the supporters of the rival team "cry more" since the victory was an irreversible event, and the only alternative for the losers is to lament their defeat. The second context is the political one. The Chola Mais meme has been used mostly by rightwing movements in Brazil, which protested against their Labor Party's policies and leaders, by focusing mainly on an operation conducted by the Brazilian Federal Police to investigate those politicians from Labor and other parties who were involved in corruption scandals (Gomes, 2016).

An exemplary usage of this meme happens when politicians are depicted. A figure found on Twitter, for example, depicts an image-macro (emerging meme) of Brazilian politician Jair Bolsonaro, whose views connect to major right-wing demands, such as opposition to public policies that increase the rights of homosexual, bisexual, or trans people, such as the right to homosexual marriage or public funding for gender transition processes, or calls for creating more strict laws to punish criminals (such as more sentence time) (Grespan \& Goellner, 2011; Lins,
Filho, \& Silva, 2016). In the meme, there is the face of the politician, along with the caption "cry more, left-wingers," a reference to the success of Jair Bolsonaro in the polls and social media (Bretas, 2017). A message similar to that sent after soccer matches is being sent: as the popularity of this particular politician grows, his opponents can only "cry" because a victory is irreversible.

We provide a brief conclusion about the Chola Mais meme. Even though it is not possible to ascertain the particular group from which this meme originated, linking the meme with context can provide cues about the repertoires it carries. The Chola Mais memes were spread mostly in two contexts: the surge in protests against the government in 2015 (the peak) and jokes about soccer. Therefore, this particular meme involves different repertoires around two different subjects. However, what Figure 5 and politician image macros have in common is the aggressive message of humiliation ("you should be crying, you lost") that the meme depicts. As explored as one of the main characteristics of Internet memes in the previous sections, the juxtaposition of funny, innocent, or cute elements with aggressive messages (Horta, 2015; Shifman, 2014) is found in this meme, as it was in the Bert is Evil meme. However, in this case, the meme depicts a direct message to be used in online interactions, that is, as a way to impose a group ideology by the "winner."

Both the Inbonha and Chola Mais memes have some common characteristics. First, both spoof beloved Brazilian characters, which are poorly drawn or misspelled (or both). The characters are also put in unusual situations, thereby subverting their meaning-something that is found in other memes too (Horta, 2015; Shifman, 2014; Wiggins \& Bowers, 2014). Furthermore, the use of child characters to depict situations that are not related to the children's universe maintains their provocateur character. Finally, both carry messages that require a specific repertoire to be understood and connected intertextually to provide arguments that will be understood by specific publics engaged in particular conversations (Arvidsson \& Caliandro, 2015).

\section{DISCUSSION AND CONCLUSIONS}

With reference to extant research on Internet memes, which we question through the analysis of the two example cases provided, we suggest that the dynamics of these objects, regarding both their production and their circulation, are as depicted in Figure 6. In the first step, memes are created inside a "local" online environment, such as a Facebook group, a discussion forum, or a community of interest, which we named as consumer collectivities, which are mainly online communities with subcultural traits. 
These settings create specific cultural and community practices and rituals, which are reflected in a vernacular lore (Howard, 2008). As such, the experiences, norms, and vocabularies that are developed in that certain digital "locality" become the shared repertoires of their participants, which manifest themselves in, and are perpetuated by, the vernacularity that is also created there (Blikstein, 2016).

\section{Figure 6. A framework explaining the dynamics of Internet memes}

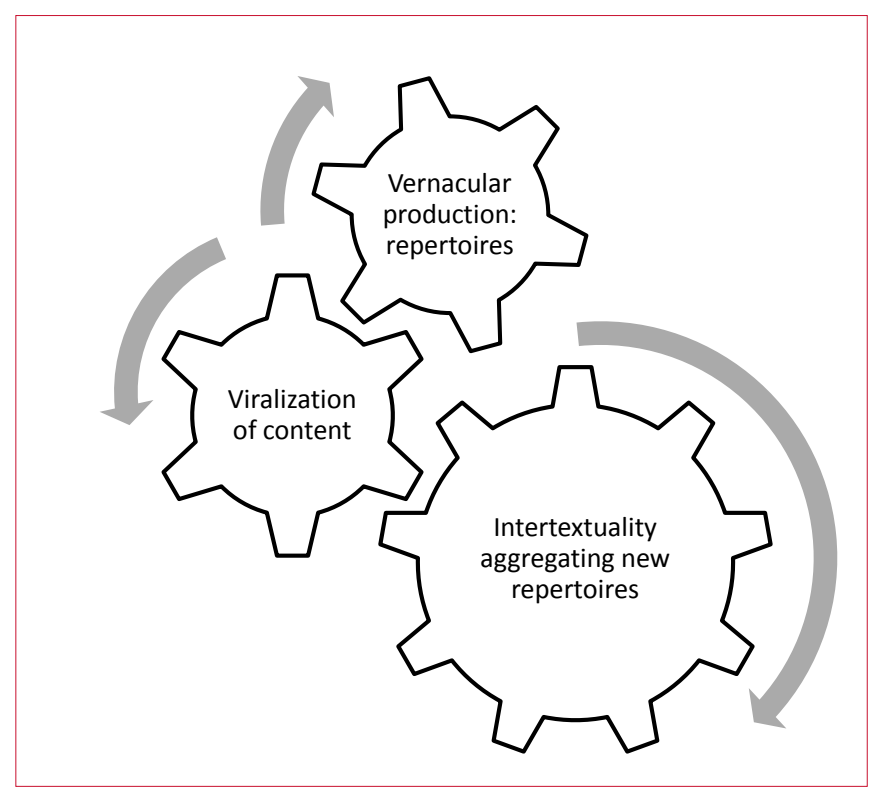

In a second step, the content that is created and used in these groups will carry some of the linguistic and cultural repertoires of the consumers who participate there. Once spread by members of these groups to a broader audience, these contents will be exporting meanings that are not necessarily understood by other groups of consumers, or other publics (Arvidsson \& Caliandro, 2015). In other words, they will carry through vernacular vocabularies the repertoires that were developed within these communities. Once the meme starts spreading, and goes viral, or, as Wiggins and Bowers (2014) put it, becomes an emerging meme, this repertoire also spreads, being "explained" to other groups by network actors, such as Buzzfeed, Vice Magazine, or the Know Your Meme platform. This process usually occurs when searches related to the meme peak. This process is important because it will amplify the understanding of the repertoire of that particular community to other audiences, providing a mass translation of the meaning of the emerging meme. This is an important element that aids in the viralization of emerging memes.
In a third step, intertextuality becomes prominent, with other groups inserting different meanings and references in the meme as they spread it around different online publics (Arvidsson \& Caliandro, 2015). Yet, the memes still carry part of the meanings given to them by the vernacular repertoires of consumers in a certain online subgroup. In that process, the intertextual nature of memes will merge different repertoires carried by different emerging memes, thereby requiring the audience to have a more tacit understanding of the juxtaposed images or frames. Different repertoires translated by different visual or linguistic representations will be connected, eliciting original responses from audiences. The intertextuality will draw from the viral processes, which must necessarily precede it; the processes will provide the cues for the audience to react to the repertoires carried by the memes.

One last key point to address is the use of brands as elements of emerging memes. In addition of being a widespread cultural element in Brazilian popular culture, Turma da Monica is a brand that encompasses more than just the comic book series. For example, it is used in several licensed products. Past literature has also understood brands as cultural icons (Holt, 2004). As such, brands became elements of popular culture that, in the Internet age, carry their own meanings, which can be further modified by consumers. How consumers interpret and relate with these cultural icons in their "local" environments is also an important element in the creation of their repertoires.

\section{Implications for consumer research and marketing theory and practice}

It is somehow surprising that the pervasiveness of Internet memes in both online culture and communication studies is not as much reflected into consumer and marketing research. This may be partially due to the relative novelty of the phenomenon combined with the long review and publishing periods of academic research (Nooney \& Portwood-Stacer, 2014). One additional reason why the phenomenon has been overlooked could be that it is only recently that consumer and marketing research have shown interest in phenomena related to language and its complexities, or the linguistic turn in general (Thompson, Arnould, \& Giesler, 2013). A last tentative explanation that we provide is that consumer and marketing scholars may still struggle to identify how to link Internet memes with more established consumer and marketing issues. To date, they seem interested in Internet memes to sharpen understanding about the underlying mechanisms of virality (e.g., through the 
elaboration of epidemiological models of contagion; Bauckhage, 2011; Guadagno et al., 2013) and the logics of cultural production within online settings (Knobel \& Lankshear, 2007; Nissenbaum \& Shifman, 2017). Our study provides two main contributions. First, it connects Internet memes research on virality and on cultural production together. The model provided in Figure 6 accounts for how cultural production precedes, and follows, virality. In doing so, it clarifies the logic and intertemporal interdependencies between these two concepts and the related streams of studies. Second, it also posits a novel way to connect the phenomenon of Internet memes with consumer and marketing research. Namely, this study argues that Internet memes are crucial to also investigate consumer online communities, where social links are derived from affinities in vernacular backgrounds and expressive practices (in our context, the fact of sharing common memes).

With reference to the use of Internet memes in consumer and marketing research to better understand the mechanisms of online virality, our work grounds two orders of conclusions. As the idea of "viral" entered the marketing world, becoming a marketing model (Holt, 2004), marketing rhetoric has reflected on the problem of the "agency" of the viral content (Miles, 2014): if the virality of any content is explained by network dynamics and online interactions generating peaks of interests in a network, marketers' actions will necessarily tend to be reactive. Memes, however, as objects that are carriers of meaning, could be predictors of possible fashions, trends, and languages that will go viral online. As marketers struggle to understand coolness and the virality of cool (Warren \& Campbell, 2014), memes could be an interesting artifact for accessing the vernacular repertoires of the communities in which they emerge. They could enable predictions and strategic planning that takes into account the "meaning" of coolness and how this coolness will enter conversations.

A second point is how memes, based on the meanings they carry, have directionality (Wiggins, 2016). In this sense, meanings are not neutral; indeed, they are objects acting as provocateurs (Horta, 2015; Shifman, 2014), but the repertoires attached to them have a specific audience. Memes stand for something, whether they are objects to pass a message against an ideologically opposed group or functioning simply "for the lulz," that is, generating disruption and laughter (Phillips, 2015).

With reference, then, to the use of Internet memes in consumer and marketing research to better understand processes of cultural production within online settings, this study shows that memes are potential carriers of meanings and vernacular repertoires between closed consumer communities and consumer publics (Arvidsson \& Caliandro, 2015). Arvidsson and Caliandro (2015) propose the idea of brand publics or consumers who are connected to brands loosely through mediations, such as hashtags. Considering how memes join the vernacular repertoires created in different communities, they enact these different repertoires intertextually. As such, as Arvidsson and Caliando (2015) propose, they are mediation devices in that they are objects carrying these meanings, connecting different repertoires of specific groups, and transmitting directionalities (Wiggins, 2016) and disruption possibilities.

\section{LIMITATIONS, AND DIRECTIONS FOR FURTHER RESEARCH}

This study contributes to linking the booming phenomenon of Internet memes with consumer and marketing research, especially by clarifying links between virality and online cultural production as much as by suggesting the role of shared expressive practices for online consumer collectivities. However, we limit our empirical analysis to one geo-cultural site, that of Brazil, and to two specific cases of Internet memes. In the interest of findings' transferability, we invite for works conducted on more geo-cultural sites and other types of memes. In addition, while this study sheds light on the use of memes to strengthen and express community links among consumers, we invite more work to dig deeper in the generative links existing between specific memes and given online consumer collectivities. ,

The following are some theoretical avenues that could be pursued. First, the question of materiality (Dant, 2005; Latour, 2007), by investigating memes as material artifacts that have agency in themselves. Second, studying memes under the lens of rhetorical theory, considering their function (Miller, 1984) and their interaction with the Internet as a medium (Lanham, 1993, 2006). Finally, looking at memes as performative objects (Harju \& Huovinen, 2015; Thompson \& Üstüner, 2015) that have a linguistic function and also reflect tensions that defy/reify power structures found within the prevalent consumer collectivities online.

\section{RAE'S NOTE}

A preliminary version of this article was presented at the International Social Networks Conference (ISONEC), promoted by Fundação Getulio Vargas, Escola de Administração de Empresas de São Paulo in 2017, São Paulo, Brazil. 


\section{REFERENCES}

Allsop, D. T., Bassett, B. R., \& Hoskins, J. A. (2007). Word-of-mouth research: Principles and applications. Journal of Advertising Research, 47(4), 398. doi:10.2501/S0021849907070419

Arvidsson, A., \& Caliandro, A. (2015). Brand public. Journal of Consumer Research, 42(5), 727-748. doi:10.1093/jcr/ucv053

Bauckhage, C. (2011). Insights into internet memes. Fifth International AAAI Conference on Weblogs and Social Media. Retrieved from https://www.aaai.org/ocs/index.php/ICWSM/ICWSM11/paper/ viewPaper $/ 2757$

Benveniste, É. (1974). Problèmes de linguistique générale. Paris, France: Gallimard.

Beran, D. (2017). 4chan: The skeleton key to the rise of Trump. Retrieved from https://medium.com/@DaleBeran/4chan-the-skeleton-key-tothe-rise-of-trump-624e7cb798cb

Blackmore, S. (2000). The meme machine. Oxford, UK: Oxford Paperbacks.

Blikstein, I. (2016). Técnicas de Comunicação Escrita. São Paulo, SP: Contexto.

Börzsei, L. K. (2013). Makes a meme instead: A concise history of internet memes. New Media Studies Magazine, 7(March), 1-29.

Bretas, V. (2017). Bolsonaro cresce para 2018 e se aproxima de Lula, diz pesquisa. Retrieved from https://exame.abril.com.br/brasil/ bolsonaro-cresce-para-2018-e-se-aproxima-de-lula-diz-pesquisa/

Brown, J. J., Broderick, A., \& Lee, N. (2007). Word of mouth communication within online communities: Conceptualizing the online social network. Journal of Interactive Marketing, 21(3), 2-20. doi:10.1002/dir

Brown, J. J., \& Reingen, P. H. (1987). Social ties and word-of-mouth referral behavior. Journal of Consumer Research, 14(3), 350-362. doi:10.1086/209118

Castells, M. (2012). Redes de Indignação e Esperança. Rio de Janeiro, RJ: Zahar.

Chola Mais / Cwy Mowe. (2016). Retrieved from http://knowyourmeme. com/memes/chola-mais-cwy-mowe

Dant, T. (2005). Materiality and society. Berkshire, UK: Open University Press.

Davison, P. (2012). The language of Internet memes. In M. Mandiberg (Ed.), The Social Media Reader (pp. 120-134). New York, NY: NYU press.

Declercq, M. (2017). Como o LDRV se tornou a espinha dorsal do Brasil memético. Retrieved from https://www.vice.com/pt_br/ article/kzzdzg/como-o-Idrv-se-tornou-a-espinha-dorsal-do-brasilmemetico

Dellarocas, C. (2006). Strategic manipulation of Internet opinion forums: Implications for consumers and firms. Management Science, 52(10), 1577-1593. doi:10.1287/mnsc.1060.0567

Evangelista, R. (2016a). Até a Mônica de verdade se rendeu à "Inbonha." Retrieved from https://www.buzzfeed.com/raphaelevangelista/ ate-a-monica-de-verdade-se-rendeu-a-inbonha?utm_term =. bvP3zbPpG1\#.payDBwKoma
Evangelista, R. (2016b). Esta é a Alice, a menina que criou a "Inbonha." Retrieved from https://www.buzzfeed.com/raphaelevangelista/ esta-e-a-alice-a-menina-que-criou-a-inbonha?utm_term=.qd $934 \mathrm{~L}$ pavz\#.vbjM9xoD5K

Fournier, S., \& Lee, L. (2009). Getting brand communities right. Harvard Business Review, (April), 105-111. Retrieved from https://hbr.org/

Godes, D., \& Mayzlin, D. (2004). Using online conversations to study word-of-mouth communication. Marketing Science, 23(4), 545-560. doi:10.1287/mksc.1040.0071

Godwin, M. (1994). Meme, counter meme. Wired. Retrieved from https://www.wired.com/1994/10/godwin-if-2/

Gomes, M. A. de M. (2016). Crítica à cobertura midiática da Operação Lava Jato. Revista Brasileira de Ciências Criminais, (122), 229-253.

Grespan, C. L., \& Goellner, S. V. (2011). "Querem, na escola, transformar seu filho de 6 a 8 anos em homossexual": Sexualidade, educação e a potência do discurso heteronormativo. FACED, 19(1), 103-122. doi:10.9771/2317-1219rf.voi19.5251

Groeger, L., \& Buttle, F. (2014). Word-of-mouth marketing: Towards an improved understanding of multi-generational campaign reach. European Journal of Marketing, 48(7/8), 1186-1208. doi:10.1108/ EJM-02-2012-0086

Guadagno, R. E., Rempala, D. M., Murphy, S. \& Okdie, B. M. (2013). What makes a video go viral? An analysis of emotional contagion and Internet memes. Computers in Human Behavior, 29(6), 2312-2319.

Harju, A. A., \& Huovinen, A. (2015). Fashionably voluptuous: Normative femininity and resistant performative tactics in fatshion blogs. Journal of Marketing Management, 31(15-16), 1602-1625. doi:10.108 o/0267257X.2015.1066837

Holt, D. B. (2004). How brands become icons: the principles of cultural branding. Boston, MA: Harvard Business School Press.

Horta, N. B. (2015). O meme como linguagem da internet: Uma perspectiva semiótica (Master's thesis). Universidade de Brasília. Retrieved from http://repositorio.unb.br/handle/10482/18420

Howard, R. G. (2005). A theory of vernacular rhetoric: The case of the "sinner's prayer" online. Folklore, 116(2), 172-188. doi:10.1080/00155870500140214

Howard, R. G. (2008). The vernacular web of participatory media. Critical Studies in Media Communication, 25(5), 490-513. doi:10.1080/15295030802468065

Howard, R. G. (2009). Crusading on the vernacular web: The folk beliefs and practices of online spiritual warfare. In T. Blank (Ed.), Folklore and the Internet: Vernacular expression in a digital world (pp. 159174). Logan, Utah: Utah State University Press.

Jenkins, H. (2006). Convergence culture: Where old and new media collide. New York, NY: NYU press.

Kates, S. M. (2004). The dynamics of brand legitimacy: An interpretive study in the gay men's community. Journal of Consumer Research, 31(2), 455-464. doi:10.1086/422122

Katz, E., \& Lazarsfeld, P. F. (1955). Personal influence: The part played by people in the flow of mass communications. New York, NY: Transaction publishers.

Kozinets, R. V. (2001). Utopian enterprise: Articulating the meanings of Star Trek's culture of consumption. Journal of Consumer Research, 28(1), 67-88. doi:10.1086/321948 
Kozinets, R. V., Hemetsberger, A., \& Schau, H. J. (2008). The wisdom of consumer crowds: Collective innovation in the age of networked marketing. Journal of Macromarketing, 28(4), 339-354. https://doi. org/10.1177/0276146708325382

Kozinets, R. V., Valck, K. De, Wojnicki, A. C., \& Wilner, S. J. S. (2010). Networked narratives: Understanding word-of-mouth marketing in online communities. Journal of Marketing, 74(2), 71-89. doi:10.1509/ jmkg.74.2.71

Knobel, M. \& Lankshear, C. (2007). Online memes, affinities, and cultural production. In C. Lankshear, M: Knobel, C. Bigum \& M. Pters (Eds.), A new literacies sampler (pp. 199-228). New York, NY: Peter Lang Publishing.

Lanham, R. A. (1993). The electronic word: Democracy, technology, and the arts. Chicago, IL: The University of Chicago Press.

Lanham, R. A. (2006). The economics of attention: Style and substance in the age of information. Chicago, IL: University of Chicago Press.

Latour, B. (2007). Reassembling the social: An introduction to actornetwork theory. Hampshire, UK: Oxford University Press.

Lins, R., Filho, D. F., \& Silva, L. (2016). A redução da maioridade penal diminui a violência? Evidências de um estudo comparado 1. Opiniao Publica, 22(1), 118-139. doi:10.1590/1807-0191201622118

Metropoles. (2016). Perfil reúne desenhos bizarros da Turma da Mônica em muros de escolas. Retrieved from https://www.metropoles. com/colunas-blogs/pipocando/perfil-reune-desenhos-bizarros-daturma-da-monica-em-muros-de-escolas

Miles, C. (2014). The rhetoric of managed contagion: Metaphor and agency in the discourse of viral marketing. Marketing Theory, 14(1), 3-18. doi:10.1177/1470593113506433

Miller, C. R. (1984). Genre as social action. Quarterly Journal of Speech, 70(2), 151-167. doi:10.1080/00335638409383686

Milner, R. M. (2013). Media lingua franca: Fixity, novelty, and vernacular creativity in Internet memes. AolR Selected Papers of Internet Research, 3, 1-5.

Mina, A. X. (2017). When Internet memes infiltrate the physical world. Retrieved from https://www.theatlantic.com/technology/ archive/2017/05/when-internet-memes-infiltrate-the-physicalworld/523887/

Mônicas Deformadas em Muros de Escolinhas. (2018). Retrieved from https://www.facebook.com/monicasdeformadas/

Muñiz, A. M., \& Schau, H. J. (2005). Religiosity in the abandoned Apple Newton brand community. Journal of Consumer Research, 31(4), 737 747. doi:10.1086/426607

Muñiz, A. M., \& Schau, H. J. (2011). How to inspire value-laden collaborative consumer-generated content. Business Horizons, 54(3), 209-217. doi:10.1016/j.bushor.2011.01.002

Nissenbaum, A. \& Shifman, L. (2017). Internet memes as contested cultural capital: The case of 4chain's/b/board. New Media \& Society 19(4), 483-501.

Nooney, L., \& Portwood-Stacer, L. (2014). One does not simply: An introduction to the special issue on memes. Journal of Visual Culture, 13(3), 248-252. doi:10.1177/1470412914551351
On a Scale of 1 to X. (2012). Retrieved from http://knowyourmeme.com/ memes/on-a-scale-of-1-to-x

Phelps, J. E., Lewis, R., Mobilio, L., Perry, D., \& Raman, N. (2004). Viral marketing or electronic word-of-mouth advertising: Examining consumer responses and motivations to pass along email. Journal of Advertising Research, 44(4), 333-348. doi:10.1017/ So021849904040371

Phillips, W. (2015). This is why we can't have nice things: Mapping the relationship between online trolling and mainstream culture. Cambridge, MA: MIT Press.

Reingen, P. H., Foster, B. L., Brown, J. J., \& Seidman, S. B. (1984). Brand congruence in interpersonal relations: A social network analysis. Journal of Consumer Research, 11(3), 771-783.

Rosenthal, B. (2014). Brand image co-creation and individual identity extension in online environments: A Facebook investigation. Escola de Administração de Empresas de São Paulo. Fundação Getulio Vargas. Retrieved from http://bibliotecadigital.fgv.br/dspace/ handle/10438/11581

Schau, H. J., Muñiz, A. M., \& Arnould, E. J. (2009). How brand community practices create value. Journal of Marketing, 73(5), 30-51. doi:10.1509/jmkg.73.5.30

Schouten, J. W., \& McAlexander, J. H. (1995). Subcultures of consumption: An ethnography of the New Bikers. Journal of Consumer Research, 22(1), 43-61.

Schroeder, J. E., \& Zwick, D. (2004). Mirrors of masculinity: Representation and identity in advertising images. Consumption Markets \& Culture, 7(1), 21-52. doi:10.1080/1025386042000212383

Scott, L. M. (1994). Images in advertising: The need for a theory of visual rhetoric. Journal of Consumer Research, 21(2), 252-273.

Scott, L. M. (2009). Theoretical realism: Culture and politics in commercial imagery. In J. F. Sherry \& E. Fischer (Eds.), Explorations in consumer culture theory (pp. 34-54). New York, NY: Routledge.

Scott, L. M., \& Vargas, P. (2007). Writing with pictures: Toward a unifying theory of consumer response to images. Journal of Consumer Research, 34(3), 341-356. doi:10.1086/519145

Shifman, L. (2014). Memes in digital culture. Cambridge, MA: MIT Press.

Sims, M. C., \& Stephens, M. (2011). Living folklore: An introduction to the study of people and their traditions. Logan, UT: Utah State University Press.

Stratton, G., \& Northcote, J. (2014). When totems beget clans: The brand symbol as the defining marker of brand communities. Journal of Consumer Culture, 16(2), 493-509. doi:10.1177/1469540514528194

Thomas, T., Price, L. L., \& Schau, H. J. (2012). When differences unite: Resource dependence in heterogeneous consumption communities. Journal of ConsumerResearch,39(5), 1010-1033. doi:10.1086/666616

Thompson, C. J., Arnould, E. J., \& Giesler, M. (2013). Discursivity, difference, and disruption: Genealogical reflections on the consumer culture theory heteroglossia. Marketing Theory, 13(2), 149-174. doi:10.1177/1470593113477889

Thompson, C. J., \& Üstüner, T. (2015). Women skating on the edge: Marketplace performances as ideological edgework. Journal of Consumer Research, 42(2), 235-265. doi:10.1093/jcr/ucv013 
Trusov, M., Bucklin, R. E., \& Pauwels, K. (2009). Effects of word-ofmouth versus traditional marketing: Findings from an Internet social networking site. Journal of Marketing, 73(5), 90-102. doi:10.1509/ jmkg.73.5.90

Warren, K. \& Campbell, M. C. (2014). What makes things cool? How autonomy influences perceived coolness. Journal of Consumer Research 41(82), 543-563.

Watts, D., \& Dodds, P. S. (2007). Influentials, networks, and public opinion formation. Journal of Consumer Research, 34(4), 441-458. doi:10.1086/518527
Wiggins, B. E. (2016). Crimea River: Directionality in memes from the Russia - Ukraine conflict. International Journal of Communication, $10,451-485$.

Wiggins, B. E., \& Bowers, G. B. (2014). Memes as genre: A structurational analysis of the memescape. New Media \& Society, 17(11), 1886-1906. doi:10.1177/1461444814535194

Wu, Y., \& Ardley, B. (2007). . The Marketing Review, 7(3), 301-310. doi:10.1362/146934707X230112 